muzea, tedy jeho osudech po zrušení Tovaryšstva v roce 1773 a vyzdvihla významné badatele, kteří se tímto tématem zabývali. Tibor Morovics (Bratislava) upozornil na analogie mezi vědeckým dílem uherského jezuity Paula Makó a aktivitami Josefa Steplinga. Badatelka z další důležité někdejší jezuitské univerzity v Trnavě Henrieta Žažová seznámila posluchače $\mathrm{s}$ dějinami tamní observatoře založené v roce 1753. Zdislav Šíma připomenul jisté, ostatně už dostatečně známé, peripetie ze života jezuitských misionářù, kteří se zabývali prrírodovědnými a geografickými výzkumy. Jan Fábry se potom věnoval rozboru některých prvků v Santiniho architektuře. Zajímavé bylo sdělení Jakuba Halody o Steplingově pozorování meteoritů, které spadly nedaleko Tábora v roce 1753.

Škoda jen, že až na závěrečné odpoledne nebyl dán prostor pro diskusi, což rozhodně neprospělo kvalitě konference, kde byla přednesena řada kvalitních př́spěvků. Pořadatelé také dostatečně nezabránili častému nešvaru na našich vědeckých setkáních, totiž svévolnému překračování času vymezeného pro jednotlivé referenty. Tento zlozvyk poškozuje ty z účastníkủ, kteří už nedostanou plný prostor pro svá vystoupení; a je de facto projevem neslušnosti a neúcty $\mathrm{k}$ druhým a kazí dojem $\mathrm{z}$ úspěšného jednání. Podobné konstatování bohužel platí pro velkou část konferencí a sympozií. Klementinská konference byla doplněna prohlídkou historických prostor budovy, které jsou ovšem pronajaty soukromé společnosti a Národní knihovna na jejich využívání nemá žádný vliv. I proto se společenský večer a slavnostní raut konaly ve Strahovském klášteře. Jednoznačně pozitivní ohlas vzbudila výstava o životě a díle Josefa Steplinga, autorem jejíhož scénáře byl Josef Smolka a na uspořádání se podílelo Oddělení rukopisů a starých tisků NK, které zapůjčilo především originální tisky. Alespoň tato výstava směla být umístěna v chodbě v přízemí před všeobecnou studovnou.

Ivana Čornejová

\title{
„Věda a moc. Věda jako moc“. \\ 7. mezinárodní konference Evropské společnosti pro dějiny vědy v Praze
}

Ve dnech 22.-24. záŕí 2016 se v Praze konala 7. mezinárodní konference Evropské společnosti pro dějiny vědy (ESHS). Tématem konference byla „Věda a moc. Věda jako moc“. Filozofická fakulta UK na Palachově náměstí v Praze hostila po celé tři dny více než 500 účastníků z pěti kontinentů. Šlo sice o „evropskou“ konferenci, přijeli však lidé ze 40 zemí, a to i z Austrálie, Afriky, Severní i Jižní Ameriky a Asie. Domácími pořadateli konference byly Ústav dějin UK a archiv UK a Společnost pro dějiny věd a techniky, prezidentem konference Petr Svobodný.

Konference ESHS, která byla založena v roce 2003, se koná každé dva roky a Praha ji hostila poprvé. Pro Prahu to byla dosud vůbec největší konference z oboru dějin věd a techniky v celé historii oboru. V čele ESHS v uplynulých dvou letech stála Karine Chemla (Francie). ESHS uděluje na svých konferencích Cenu Gustava Neuenschwandera za celoživotní př́nos oboru dějiny vědy a techniky, kterou v Praze obdržela Nancy Siraisi (USA). Poprvé v historii ESHS byly na pražské konferenci předneseny dvě vyzvané přednášky mladých historiků vědy a techniky, a sice Elaine Léong (Velká Británie, Německo) o vědě v 17. století a Massimiliana Badina (Španělsko) o dějinách kvantové fyziky. 
V zahajovacím ceremoniálu si shromáždění též připomnělo významné životní jubileum př́tomné docentky Soni Štrbáňové, zakládající členky ESHS a její prezidentky v letech 2010-2012.

V rámci konference zazněly kromě přednášek mladých vědců také dvě další plenární přednášky, a sice z úst nového prezidenta ESHS pro období 2016-2018 Antoni Maleta (Španělsko) a od Roberta Foxe, který na pražské konferenci obdržel Koyrého cenu udělovanou DHST/ICHST z rukou jejího prezidenta Efthymia Nicolaidise (Řecko).

Účastníci zasedali v 29 sekcích, sestavených z abstrakt zaslaných samostatně z iniciativy přednášejících, a v 50 sympoziích předem obeslaných a připravených, jejichž organizátoři je předložili pořadatelům již jako celek. Po celé trř dny bylo paralelně v permanenci 15 místností, kde jednání probíhala.

ESHS a její aktivity jsou tradičně zaměřeny především na historii přírodních věd, a to jak na vlastní vývoj objevů, inovací a vědeckých postupů, tak na vývoj vědeckých institucí, působících v oblasti přírodních věd. To se odrazilo i v náplni pražské konference. Sekce i sympozia se zabývaly historií matematiky, fyziky, chemie, astronomie, geografie i dalších oborů. Vedle toho zasedly sekce a sympozia i k jednání o gender, filozofii vědy i o dějinách humanitních oborů. Přímý vztah $\mathrm{k}$ dějinám vysokého školství měla sekce č. 6 a sympozium č. 367 zaměřené na vztah mezi univerzitami, vědou a politikou od Velké francouzské revoluce do druhé poloviny 20. století (s dưrazem spíše na novější dějiny) a dále pak sympozium č. 197 sledující nejrůznější aspekty mad’arského vysokého školství od jeho středověkých počátků. Jednotlivé relevantní príspěvky ale bylo možné najít i v jiných sekcích a sympoziích, a to např. i $\mathrm{k}$ tak netradičním tématům, jako je studentské rozhlasové vysílání v prostředí lidově demokratického Polska (sympozium č. 225, př́spěvek Urszuly Doliwa).

$\mathrm{K}$ dějinám pražské univerzity se přímo vztahovaly př́íspěvky pracovníků ÚDAUK a spř́zněných institucí, konkrétně M. Sekyrkové (o prvních studentkách středoevropských univerzit), P. Svobodného (o působení profesorů lékařství na univerzitách v Praze, Brně a Bratislavě po roce 1918), J. Jareše (o vysokoškolské reformě v Československu po roce 1946), M. Šimůnka (o „vyhnaných“ profesorech př́rodovědecké fakulty pražské německé univerzity v letech 1938-1939), M. Hykšové (o matematikovi Karlu Rychlíkovi) a P. Hyklové s M. Šolcem (o astronomovi Vincenci Nechvílem).

Velká pozornost byla věnována vědě v bývalém východním bloku, a to již pro období dlouhého 19. století. Největší pozornost na tomto poli se však upřela na období po roce 1945 , respektive 1948. Hovořilo se o situaci v akademiích věd, na univerzitách, o podřizování vědy ideologii i odporu proti tomu a emigraci.

Přriští, osmá konference ESHS se bude konat 15.-17. září 2018 v Londýně, kam závěrem pozvali prítomní pořadatelé z několika britských vědeckých institucí.

Milada Sekyrková - Marek Ďurčanský 